\title{
Dinamika Industri Gula Sejak Cultuurstelsel Hingga Krisis Malaise Tahun 1830 - 1929
}

\author{
Yusuf Perdana ${ }^{1}$, Henry Susanto ${ }^{1}$, Yustina Sri Ekwandari ${ }^{1}$ \\ Pendidikan Sejarah FKIP Universitas Lampung \\ JI. Prof. Dr. Ir. Sumantri Brojonegoro No. 1, Gedong Meneng, Kec. Rajabasa, Kota Bandar \\ Lampung \\ Email : $\underline{\text { Yusuf.perdana@FKIP.Unila.ac.id }}$
}

Received 11 July 2019; Received in revised form 10 August 2019; Accepted 24 August 2019

\begin{abstract}
Abstrak
Tujuan penelitian ini adalah untuk menganalisis sejarah industri gula di Hindia Belanda pada kurun waktu 1830-1929, dampak cultuurstelsel terhadap industri gula, pelaksanaan Undang-Undang Agraria 1870, hingga dampak krisis malaise terhadap produksi gula Hindia Belanda. Metode yang digunakan dalam penelitian ini adalah metode sejarah. Langkahlangkah yang dilakukan oleh peneliti diantaranya adalah heuristik atau pengumpulan sumber, kritik sumber atau menelaah kebenaran sumber-sumber yang sudah ada, interpretasi data atau penafsiran sejarah, keempat adalah historiografi. Pada penelitian ini dijelaskan bahwa industri gula di Hindia Belanda pada kurun waktu 1830 hingga 1929 mengalami pertumbuhan. Bahkan kurun waktu 1840-1849 industri gula menempati keuntungan terbesar kedua setelah kopi. Berlakunya undang-undang agrarian pada tahun 1870 berdampak pada masuknya modal asing yang berakibat meningkat drastis produksi gula di Hindia Belanda hingga menjadi salah satu eksportir gula terbesar di dunia. Perang Dunia I menimbulkan kekacauan ekonomi ditambah turunnya bursa saham New York berakibat pada lesunya pasar dunia terutama industri gula yang dikenal dengan krisis malaise. Kesimpulan penelitian yakni krisis malaise menyebabkan industri gula menurunkan produksinya secara drastis dan berefek pada migrasinya tenaga perkebunan ke daerah lain dan beralih ke sektor industri dan jasa.
\end{abstract}

Kata Kunci: Industri Gula, Cultuurstelsel, Krisis Malaise

\begin{abstract}
The purpose of this study was to analyze the history of the sugar industry in the Dutch East Indies in the period 1830-1929, the impact of the cultuurstelsel on the sugar industry, the implementation of the Agrarian Law 1870, to correct the crisis of malaise on the sugar production of the Dutch East Indies. The method used in this study is the historical method. The steps taken by the researcher answer are heuristic sources or sources, sources of criticism or examine existing sources, interpret data or historical interpretation, meaning historiography. In this study, discussing the sugar industry in the Dutch East Indies in the period 1830 to 1929 increased. At least in the period 1840-1849 the sugar industry got the second biggest profit after coffee. The enactment of the agrarian law in 1870 had an impact on capital inflows which resulted in a drastic increase in sugar production in the Dutch East Indies increasing to become one of the largest sugar exporters in the world. World War I faced economic challenges plus the New York stock exchange resulted in the sluggish world market of the main industry known as the malaise crisis. Conclusion of research on the crisis of malaise caused the sugar industry to decrease production drastically and have an effect on the migration of workers to other regions and switch to the industrial and service sectors.
\end{abstract}

Keywords: Sugar Industry, Cultuurstelsel, Malaise Crisis 
PENDAHULUAN

Pada Era Abad ke-21 ini, Indonesia merupakan salah satu Negara Berkembang di Dunia terutama kawasan Asia Tenggara yang mendapat perhatian khusus dari Negara lain dalam menginvestasikan modalnya ke beberapa perusahaan baik Badan Usaha Milik Negara (BUMN) maupun perusahaan swasta di Indonesia. Masuknya Modal Asing ke Indonesia dalam bidang Industri bukanlah hal baru, khususnya Industri Gula pada zaman kolonial Hindia Belanda yang padat modal. Indonesia merupakan salah satu Negara kepulauan terbesar di dunia yang memiliki sejarah panjang mulai dari zaman prasejarah sampai zaman sejarah (Kabib, 2019: 1).

Sejarah mencatatat bahwa Indonesia yang dulu bernama Hindia Belanda pernah menorehkan prestasi menjadi salah satu pemasok gula terbesar di Dunia pada zaman Kolonial Hindia-Belanda. Bahkan, Prestasi ini tentunya dapat diraih dengan usaha yang keras, serta tidak lepas dari sistem tanam paksa (Cultuurstelsel). Selain itu, padatnya Pulau Jawa hingga kontur tanah di sekitar pesisir Pantai Utara Jawa yang cocok untuk tanaman tebu merupakan salah satu faktor terpenting dalam mengundang investor asing menanamkan modalnya pada sektor industri gula di Wilayah Hindia Belanda.
Modal merupakan sebuah pondasi atau unsur penting dalam bidang ekonomi, khususnya dalam perkembangan industri gula. Merujuk perkataan Prof. Van Niel bahwa penyertaan modal dalam Cultuurstelsel pertama-tama bukan berasal dari orangorang atau institusi-institusi keuangan di Barat. Permodalan untuk pabrik-pabrik gula yang dikelola pihak swasta datangnya justru dari berbagai pihak di Jawa sendiri, seperti para pensiunan pegawai negeri, perusahaan-perusahaan impor-ekspor dan sudah tentu para saudagar Cina (Leirissa dkk, 2012: 6263). Berawal dari masuknya modal asing maka kududukan pemerintah digantikan oleh kaum usahawan perkebunan, kerja paksa diganti dengan kerja upah, serta kewajiban serah tanah diganti dengan sewa tanah (Trijono, 2011: 56). Pada tahun 1830 Pemerintah Hindia Belanda menunjuk Gubernur Jenderal yang baru yaitu Van Den Bosch yang mempunyai gagasan sistem tanam paksa atau Cultuurstelsel (Muffidatut, 2012: 36).

Perkebunan tebu merupakan tahapan pertama dari industri gula (Leirissa dkk, 2012: 67). Tebu merupakan bahan baku industri gula yang termasuk dalam salah satu tanaman dalam Cultuurstelsel. Tanaman tebu yang menghasilkan gula, memang menyediakan tidak hanya pendapatan yang luar biasa besar saja, namun juga lapangan pekerjaan yang 
HISTORIA: Jurnal Program Studi Pendidikan Sejarah Volume 7 (2) 2019

ISSN 2337-4713 (E-ISSN 2442-8728)

melimpah atau bisa dikatakan jenis industri merupakan yang padat karya (Winin, 2018: 174).

Industri gula merupakan salah satu industri modern pada saat pemerintahan Hindia-Belanda. Usaha industri modern harus memenuhi syaratsyarat tertentu yang amat berbeda dengan usaha secara tradisional. Industri sebagai bidang usaha harus bekerja secara melembaga, sehingga keberadaannya harus bersifat formal. Usaha Industri harus memiliki ijin, produk sebagai hasil usaha, diperlukan manajemen yang menggerakkan seluruh aktifitasnya, bahkan seluruh aktifitasnya tercatat secara tertib dan teratur dalam kurun waktu tertentu yang tercantum mulai dari perencanaan hingga pencapaian hasil, serta distribusi sampai pemasaran produknya (Nurhadi, 2011: $3)$.

Sistem perkebunan diwujudkan dalam bentuk usaha pertanian skala besar dan kompleks, bersifat padat modal (capital insentive), penggunaan areal pertanahan luas, organisasi tenaga kerja besar, pembagian kerja rinci, penggunaan tenaga kerja upahan (wage labour), struktur hubungan kerja yang rapih dan penggunaan teknologi modern, spesialisasi, sistem administrasi dan birokrasi, serta penanaman tanaman komersial (commercial corps) yang ditujukan untuk komoditi ekspor di pasaran dunia (Kartodijo \& Suryo, 1991 : 4).

Tebu bukan tanaman baru yang dikenalkan oleh Belanda, Ham menuturkan bahwa tebu sudah ada di Pulau Jawa sebelum Belanda datang dan diperkirakan dibawa oleh orang Arab yang mengolahnya menjadi gula secara primitive (Ham, 2002: 64). Pabrik gula pertama kali hadir di Hindia Belanda berada di Pulau Jawa, yang menyebar sepanjang dari Jawa Barat hingga daerah Jawa Timur, terutama di daerah pesisir pantai utara jawa. Pemilihan daerah pesisir sebagai pembangunan pabrik gula tidak lepas dari efisiensi dalam proses bongkar muat gula melalui pelabuhan-pelabuhan di pesisir pantai utara Jawa.

Perkembangan Industri gula memberikan keuntungan yang besar untuk pemiliknya dan memberikan pajak untuk pemerintah kolonial. Berkat keuntungan dari perdagangan gula, beberapa kota di Pulau Jawa berkembang pesat, seperti kota pelabuhan Semarang dan Surabaya, dan kota-kota lainnya. Melalui perkebunan tebu, masyarakat Pulau Jawa mengenal upah yang diberikan dalam bentuk alat pembayaran yang sah atau uang. (Poesponegoro\&Notosusanto, 1984: 185). Namun, kejayaan industri gula di jajahan Hindia-Belanda tidak serta merta membawa kenikmatan yang sama 
untuk pribumi, terlebih dengan hadirnya krisis Malaise pada tahun 1929 yang membuat Industri gula terpuruk dengan ekspor hasil perkebunan jenis gula yang menurun drastis.

Melihat berbagai latar belakang diatas menarik untuk dibahas lebih mendalam perkembangan Industri Gula dalam kurun waktu Cultuurstelsel hingga Krisis Malaise, karena industri gula memberikan dampak yang besar baik itu kepada Pemerintah Hindia Belanda maupun masyarakat Hindia Belanda. Maka penulis ingin mengetahui dinamika yang terjadi dalam industri gula, dari mulai diterapkannya Cultuurstelsel pada tahun 1830, pelaksanaan Undang-Undang Agraria 1870, hingga dampak dari krisis Malaise pada tahun 1929 terhadap industri gula di jajahan Hindia-Belanda.

\section{METODE}

Penelitian ini menggunakan metode penelitian sejarah. Metode yang digunakan ialah menelaah sumbersumber yang ada serta berisi informasiinformasi yang ada pada waktu itu atau satu zaman serta dilaksanakan dengan cara sistematis dan kronologis. Metode sejarah mempunyai empat langkah yang berurutan yaitu Heuristik, Kritik, Interpretasi dan Historiografi (Gottschalk, 2008: 39).
Langkah pertama dalam penelitian ini adalah Heuristik, kata heuristik berasal dari bahasa Yunani heurishen, artinya memperoleh, heuristik adalah suatu teknik, suatu seni dan bukan suatu ilmu. Heuristik merupakan suatu keterampilan dalam menemukan, menangani dan memperinci bibliografi atau mengklasifikasikan dan merawat catatan-catatan (Abdurrahman, 1999: 55). Pada tahap Heuristik ini peneliti mengumpulkan data-data serta sumbersumber yang terkait baik dari Buku, Jurnal, arsip, dokumen, surat kabar dan lain sebagainya yang berhubungan atau mengenai perkebunan, tanaman tebu, industri gula, cultuurstelsel, undangundang-undang agrarian hingga krisis malaise.

Langkah kedua adalah kritik sumber. Kritik sumber adalah proses pengujian sumber apakah asli atau bukan serta apakah bisa dipertanggung jawabkan atau tidak. Kritik sumber terdapat dua macam, yaitu kritik ekstern yang berarti menyelidiki untuk menentukan keaslian dengan menjawab pertanyaan $5 \mathrm{~W}+1 \mathrm{H}$. Sedangkan, kritik intern adalah penentuan dapat tidaknya keterangan dalam dokumen digunakan sebagai fakta sejarah (Yass, 2004: 3536). Disinilah penulis menguji sumbersumber yang ada melalui kritik ekstern dan intern. 
HISTORIA: Jurnal Program Studi Pendidikan Sejarah Volume 7 (2) 2019

ISSN 2337-4713 (E-ISSN 2442-8728)

Langkah ketiga adalah
Interpretasi Data. Dalam tahap

Interpretasi ini peneliti menghubungkan data yang ada serta memberikan penafsiran apa yang ada dalam datadata. Penafsiran atas fakta harus dilandasi obyektif. Kalaupun dalam hal tertentu bersikap subyektif rasional dan jangan subyektif emosional. Rekonstruksi peristiwa sejarah harus menghasilkan sejarah yang benar atau mendekati kebenaran (Kuntowijoyo, $1994: 100)$.

Langkah terakhir adalah Historiografi. Pada tahap ini merupakan tahap penulisan serta pemaparan datadata penelitian sejarah yang dilakukan (Abdurrahman, 2011: 67) dalam tahap historiografi ini peneliti bertujuan hasil penelitian yang telah ditulis dapat memberikan sebuah gambaran yang jelas mengenai industri gula sejak Cultuurstelsel hingga Krisis Malaise pada tahun 1830-1929.

\section{HASIL DAN PEMBAHASAN}

\section{Munculnya Perkebunan Tebu dan Industri Gula}

Dalam Sejarah pada masa pemerintahan Hindia Belanda, Industri gula sangat berperan penting dalam menghasilkan pundi-pundi uang pada kantong-kantong Belanda, baik pajak, sewa tanah, tanam paksa hingga untuk melunasi hutang-hutang di negeri
Belanda sendiri. Konteks Hindia-Belanda sebagai daerah jajahan pada tahun 1930 merupakan saat dimulainya Indutrialisasi. Awal mula penanaman tebu secara besar-besaran adalah masa Sistem Tanam Paksa, yang memberikan keuntungan besar untuk kas Negara kolonial. Setelah Sistem Tanam Paksa dihentikan, perkebunan tebu dilakukan oleh pengusaha-pengusaha swasta. Perluasan perkebunan tebu tidak pernah melampaui Pulau Jawa. Jenis tanah dan pola pertanian di Pulau Jawa lebih sesuai untuk penanaman tebu. keuntungan yang besar dari perkebunan tebu mendorong pendirian pabrik-pabrik gula yang menjadi motor penggerak perekonomian Hindia Belanda (Poesponegoro \& Notosusanto, 1984: 184). Sepanjang abad kesembilan belas, surplus tanah yang dihasilkan oleh koloni telah diserap setiap tahun sebagai upeti ke kas Belanda (Agus \& Isbandiyah, 2018: 404)

Hingga sampai pada akhir pemerintahan kolonial perkebunan tetap merupakan tulang punggung ekonominya, notabene daerah jajahan adalah gabus tempat negeri induk mengapung (Kartodijo \& Suryo, 1991: 141). Perlu dicatat, bahwa dengan banyaknya keuntungan yang diperoleh dari usaha gula, banyak orang-orang swasta mengadakan kontrak dengan pemerintah untuk mengusahakan tanaman tebu. Tebu dikenal di seluruh 
kepulauan dan pohonnya banyak tumbuh di Jawa dimana memiliki beberapa varietas. Pohon tebu yang paling bagus batangnya adalah yang berwarna ungu gelap, dan tingginya sekitar 10 kaki (Raffles. $2008: 81$ ).
Pada tahun 1837 produksi gula dari perusahaan swasta kira-kira separuh dari produksi gula pemerintah (Kartodijo \& Suryo, 1991: 60). Perbandingan produksi Pemerintah dan Produksi Swasta dapat dilihat pada tabel sebagai berikut:

Tabel 1. Produksi Gula Pemerintah dan Swasta, 1837-1865 (Dalam 1000 Pikul)

\begin{tabular}{|c|c|c|}
\hline Tahun & $\begin{array}{c}\text { Produksi } \\
\text { Pemerintah }\end{array}$ & Produksi Swasta \\
\hline $1837-1838$ & 500 & 275 \\
\hline 1850 & 1,406 & $?$ \\
\hline 1855 & 1,352 & 310 \\
\hline 1860 & 1,774 & 307 \\
\hline 1865 & 1,831 & 374 \\
\hline
\end{tabular}

(D.H Burger, 1960: 227)

Penyelenggaraan penanaman

tebu dibawah peraturan pemerintah setelah tahun 1830 dipusatkan pada perjanjian-perjanjian kontrak. Perjanjian kontrak dilakukan pada dua tahapan untuk dua aspek produksi gula yang terpisah. Kontrak tahap pertama dibuat oleh pemerintah lokal dengan desa tujuannya adalah mengatur penanaman tebu di bagian tertentu tanah desa, memelihara serta menebang tebu dan awalnya, mengangkut tebu ke pabrik. Tahapan kontrak lainnya adalah antara pemerintah lokal yang diwakili pejabat belanda dengan operator (pengusaha) penggilingan gula yang dengan pinjaman uang pemerintah membangun pabrik, meengolah tebu dan menyerahkan gula kepada pemerintah dengan harga yang ditentukan (Van Niel, 2003: 40). Dari sistem perjanjian kontrak dapat dilihat jika permodalan asing hingga pihak swasta turut serta dalam pengelolaan pabrik gula di Hindia-Belanda.

Industri gula memainkan peran penting dalam perekonomian Hindia Belanda. Melalui inndustri gula Van Den Bosch ingin mengeksploitasi Hindia Belanda secara besar-besaran di bidang perkebunan. Produksi pertanian di Jawa terutama ditujukan kepada pasar dunia (Handinoto, 2015: 126). Konsentrasi Industri gula di Pulau Jawa tidak lepas dari kepadatan penduduk Pulau Jawa, karena pada hakekatnya Industri ini adalah padat karya. Robert Van Niel menyatakan bahwa Sistem Tanam Paksa 
HISTORIA: Jurnal Program Studi Pendidikan Sejarah Volume 7 (2) 2019

ISSN 2337-4713 (E-ISSN 2442-8728)

di Jawa ini telah mengungkap dua kenyataan sejarah. Pertama, Jawa abad ke-19 menjadi sumber penghasil komoditas ekspor penting bagi pasar dunia. Kedua, pulau Jawa memiliki kekayaan sumber daya manusia sangat murah yang dimanfaatkan sebagai tenaga kerja untuk kebutuhan sistem Tanam Paksa (Van Niel, 2003: xi).

\section{Berbagai faktor pendukung} dalam pelaksanaan Liberalisasi ekonomi pada waktu itu, membuat pemerintah Hindia Belanda benar-benar tidak mau membiarkan kesempatan sekecil apapun tidak dimaksimalkan. Mulai dari penanaman tebu yang dikontrol pemerintah Hindia Belanda melalui tanam paksa hingga Pendirian pabrik gula yang melibatkan swasta denga hasil produksi gula yang diserahkan kepada pemerintah denga standar harga yang sudah ditetapkan oleh pemerintah Kolonial Hindia Belanda pada waktu itu. Berbagai sistem diterapkan oleh Belanda untuk memaksimalkan eksploitasi Negara jajahan, diantaranya adalah perluasan lahan dan hasil panen tebu yang makin besar, serta perbaikan dalam pengolahannya, melipat gandakan produksi gula dari Jawa sampai empat kali selama tiga dekade pertama abad ke-20. Nilai ekspornya lebih dari 300 juta Gulden di masa keemasan tahun 1920-an. Pada masa itu, jawa merupakan salah satu eksportir gula di dunia yang utama (Hiroyosi, dkk, Yogyakarta: 49).

Industri Gula berdampak positif dan negatif bagi kaum pribumi. Dari keuntungan pengenalan tanaman ekspor dengan pasaran dunia, sistem sewa tanah hingga kemelaratan penduduk pribumi karena harus menyerahkan tanaman wajib kepada pemerintah Hindia Belanda. Penanaman tebu dengan industri gula merupakan satu sistem yang harus sinkron. Antara masa pergantian abad dan ambang pintu zaman malaise, perkebunan-perkebunan gula tetap makmur, namun jumlahnya tidak meningkat lagi, bahkan cenderung terus menurun. Penambahan terjadi dalam rata-rata luas areal yang ditanami tebu untuk setiap pabrik penggiling, dan produktivitasnya per area. Keduanya dikarenakan kemajuan teknologi yang memungkinkan pengangkutan menjadi lebih cepat, penggilingan yang efisien, dan pengembangan jenis tebu yang baru. Jenis POJ 1878 diperkenalkan pada tahun 1924. Pengenalan jenis tebu yang baru tersebut menjadi tonggak penting dalam industri gula.

\section{Cultuurstelsel}

Pada tahun 1830 Johannes Van Den Bosch tiba di Jawa sebagai Gubernur Jenderal yang baru serta memperkenalkan gagasannya mengenai Cultuurstelsel. Rencana Van Den Bosch 
ialah bahwa setiap desa harus menyisihkan sebagaian tanahnya guna ditanami komoditas ekspor (khususnya tebu, kopi dan nila). Untuk dijual dengan harga yang sudah ditentukan oleh Belanda. Sehingga desa akan mampu melunasi utang pajak tanahnya, dan Van Den Bosch memperkirakan bahwa 20\% (kelak 33\%) dari hasil panen desa tersebut akan cukup memadai untuk tujuan ini. Apabila pendapatan desa dari penjualan hasil panennya kepada pemerintah lebih banyak dari pajak tanah yang harus dibayarnya, maka desa tersebut akan menerima kelebihan-kelebihannya, namun, apabila kurang, desa tersebut tetap harus membayar kekurangannya dari sumbersumber lain (Ricklefs, 2008: 260-261).

Meskipun dalam kenyataannya yang wajib menanam tanaman ekspor itu rakyat, tetapi dalam abad-abad itu sesungguhnya hanya melakukan loyalitas kepada pemimpin tradisionalnya, yakni para bupati, melalui aparat birokrasi tradisional yang lebih rendah (Wasino, 2014: 6). Terdapat beberapa aturan dalam Sistem Tanam Paksa yang diantaranya tertera dalam Staatsblad (Lembaran Negara) tahun 1834, No. 22 jadi beberapa tahun setelah Sistem Tanam Paksa mulai dijalankan di Pulau Jawa yang berbunyi seperti berikut:

1. Persetujuan-persetujuan akan diadakan dengan penduduk agar mereka menyediakan sebagian dari tanahnya untuk tanaman dagangan yang dapat dijual di pasaran Eropa.

2. Bagian dari tanah pertanian yang disediakan penduduk untuk tujuan ini tidak boleh melebihi seperlima dari tanah pertanian yang dimiliki penduduk desa.

3. Pekerjaan yang diperlukan untuk menanam tanaman dagangan tidak boleh melebihi pekerjaan yang diperlukan untuk menanam padi,

4. Bagian dari tanah yang disediakan untuk menanam tanaman dagangan dibebaskan dari pembayaran pajak tanah.

5. Tanaman dagangan yang dihasilkan di tanah-tanah yang disediakan, wajib diserahkan kepada pemerintah Hindia Belanda, jika nilai hasil-hasil tanaman dagangan yang ditaksir itu melebihi pajak tanah yang harus diabayar rakyat, maka selisih positifnya harus diserahkan kepada rakyat.

6. Panen tanaman dagangan yang gagal harus dibebankan kepada pemerintah, sedikit-dikitnya jika kegagalan ini tidak disebabkan oleh kurang rajin atau ketekunan dari pihak rakyat.

7. Penduduk desa mengerjakan tanahtanah mereka di bawah pengawasan kepala-kepala mereka, sedangkan pegawai-pegawai Eropa hanya membatasi diri pada pengawasan apakah membajak tanah, panen dan 
HISTORIA: Jurnal Program Studi Pendidikan Sejarah Volume 7 (2) 2019

ISSN 2337-4713 (E-ISSN 2442-8728)

pengangkutan tanaman-tanaman

berjalan dengan baik dan tepat pada waktunya (Poesponegoro \& Notosusanto, 1984: 99-100).

Sistem Tanah Paksa atau Cultuurstelsel bukan hanya dijalankan tanpa perangsang financial, bagi para pegawai Belanda maupun para bupati dan kepala desa yang dapat menunaikan tugas dengan baik, pemerintah memberikan perangsang financial yag disebut Cultuurprocenten (prosenan tanaman). Cultuurprocenten itu berupa persentase tertentu dari penghasilan yang diperoleh dari penjualan tanaman ekspor yang diserahkan oleh para pegawai tersebut, jika mampu melampaui target produksi yang telah ditentukan pada setiap desa (Kartodirjo\&Suryo, 1991: 64). Hal inilah yang pada akhirnya para pejabat tradisional menekan petani petani untuk menyerahkan hasil tanaman ekspornya hingga melampaui batas yang ditentukan.

Penghapusan sistem tanam paksa secara berangsur-angsur, dimulai dari yang paling sedikit mendatangkan keuntungan contohnya adalah lada pada tahun 1862. Bagi daerah-daerah yang melaksanakannya, mengakibatkan perubahan-perubahan di dalam sistem perpajakan colonial, tetapi ini tidak berarti bahwa wajib kerja tanpa upah tidak diperlukan lagi. Wajib kerja tetap dikerahkan untuk pembangunan sarana dan prasarana, selama paruh abad ke-19 pembangunan jalan dan saluran irigasi mengalami perluasan besar-besaran dan juga dipertahankan sebagai bagian upah untuk para pejabat desa (Breman, 1986: 170).

\section{Gula Kurun Waktu 1832-1925}

Keuntungan yang menjanjikan dalam industri gula membuat orangorang Eropa berbondong-bondong mendirikan pabrik gula. Sejak 1830, ketika intensifikasi penanaman tebu didukung oleh kebijakan politik tanam paksa (cultuurstelsel), mesin-mesin penggilingan tebu juga dimodernisasi agar produksi gula sejalan dengan hasil penanaman tebu yang meningkat tajam. Sejak 1835, di sekitar Surabaya mulai bermunculan pabrik gula seperti di Buduran, Waru, Karang Bong, Tanggulangin dan Ketabang. Pada 1838, berdiri pabrik gula di Candi, Watutulis, Balong Bendo, dan Gedek. Setahun berikutnya berdiri pabrik gula di Singkalang, Krian, Bulang dan Ketegan. Pada 1840 berdiri lagi pabrik gula di Sruni. Sebagian besar pabrik gula tersebut dimiliki oleh orang Eropa (Basundoro, 2012: 244)

Keuntungan pemerintah yang dihasilkan dari industri gula sangat besar, industri gula menempati urutan kedua setelah kopi dengan keuntungan paling banyak di bidang perkebunan pada kurun waktu 1840 hingga 1849. 
Prof. Fasseur memberikan uraian sebagai berikut:

perbandingan keuntungan pemerintah

Tabel 2. Keuntungan Pemerintah

\begin{tabular}{|c|c|c|c|c|}
\hline Tahun & Kopi & Gula & Indigo & Cochinela \\
\hline $1840-1844$ & 40.277 .637 & 8.212 .907 & 7.835 .77 & 20.421 \\
\hline $1845-1849$ & 24.549 .042 & 4.136 .060 & 7.726 .362 & 519.661 \\
\hline
\end{tabular}

(Fasseur, 1992: 37)

Produksi gula terlihat mencolok berlipat ganda. Pertumbuhan perkembangannya mulai dari beberapa produksi gula dapat dilihat pada tabel tahun awal sistem tanam paksa yakni berikut: antara tahun 1832 sampai 1925 sangat

Tabel 3. Produksi Gula Tahun 1832-1925

\begin{tabular}{|c|c|c|c|}
\hline Tahun & $\begin{array}{c}\text { Areal penanaman } \\
\text { (bau) }\end{array}$ & $\begin{array}{c}\text { Produksi Gula dalam } \\
\text { pikul }\end{array}$ & $\begin{array}{c}\text { Produksi rata-rata gula } \\
\text { per bau }\end{array}$ \\
\hline 1832 & - & +100.000 & $+6,5$ \\
\hline 1840 & 44.666 & +752.000 & $+14,6$ \\
\hline 1870 & 54.176 & 2.440 .000 & +45 \\
\hline 1900 & 128.301 & 12.050 .544 & 116 \\
\hline 1913 & 204.778 & 23.736 .186 & 148,2 \\
\hline 1925 & 251.878 & 37.295 .331 & 93,75 \\
\hline
\end{tabular}

(Gonggrijp, 1938: 149)

Peningkatan yang mencolok mulai pada tahun 1870 semenjak diterapkannya Undang-Undang Agraria yang berdampak pada banyaknya para pengusaha swasta terutama dari Eropa berdatangan ke Hindia Belanda untuk membuka usaha baru (Triesca \& Mastuti, 2016: 656). Peraturan-peraturan dalam UndangUndang Agraria pada tahun 1870 tertuang sebagai berikut:
1. Tanah milik rakyat tidak dapat diperjual belikan kepada nonpribumi.

2. Disamping itu tanah domain pemerintah sampai seluas 10 bbau dapat dibeli oleh non pribumi untuk keperluan bangunan perusahaan.

3. Untuk tanah lebih domain lebih luas ada kesempatan bagi non pribumi memiliki hak guna, ialah:

a. Sebagai tanah dan hak membangun (recht van postal, disingkat RVO); 
HISTORIA: Jurnal Program Studi Pendidikan Sejarah Volume 7 (2) 2019

ISSN 2337-4713 (E-ISSN 2442-8728)

b. Tanah sebagai erfpacht (hak sewa serta hak mewariskan) untuk jangka waktu 75 tahun (Kartodirjo \& Suryo, 1991: 88).

Berlakunya Undang-Undang Agraria merupakan satu alat produksi pokok dengan kata lain tanah telah diliberalisasikan, maka terbuka kesempatan seluas-luasnya untuk membuka perusahaan perkebunan (Kartodirjo \& Suryo, 1991: 80). Salah satu wilayah yang menjadi tujuan untuk penanaman modal adalah Malang. Malang merupakan daerah yang sangat cocok untuk perkebunan karena memiliki karakteristik tanah yang subur,udara yang sejuk karena berada di daerah tinggi dan dikelilingi pegunungan, serta memiliki jarak yang tidak terlalu jauh dengan pusat pertumbuhan ekonomi pada waktu itu, yaitu Kota Surabaya (Basundoro, 2009: 238).

Dampak dari perluasan areal perkebunan, juga berpengaruh pada meningkatnya produksi per bau, antara lain karena hasil pemakaian bibit unggul hasil penelitian dan percobaan. Hal itu terjadi sejak 1900-1913, dapat dikatakan kurun waktu tersebut industri gula mengalami kemajuan yang spektakuler (Kartodirjo\&Suryo, 1999:
88). Menjamurnya perkebunan swasta turut serta membuat Areal Perkebunan Swasta dan Pemerintah yang ditanami tebu untuk suplai pabrik-pabrik gula pada kurun waktu 1865-1914 turut serta berlomba untuk memperluas areal perkebunan tebu.

Pada kurun waktu 1865-1914 luas perkebunan tebu baik swasta dan pemerintah naik turun. Naik turunnya luas areal perkebunan tebu tersebut disebabkan oleh berbagai faktor salah satunya adalah dihapuskannya cultuurstelsel sedikit demi sedikit, ketika pemerintah kolonial menghapuskan penanaman paksa komoditas pertanian Negara di wilayahnya Hindia Belanda. Penghapusan tersebut dimulai dari yang paling sedikit mendatangkan keuntungan atau tidak menguntungkan sama sekali seperti lada pada tahun 1862, cengkih dan pala pada tahun 1864, nila, teh dan kayu manis pada tahun 1865, tembakau pada tahun 1866 dan yang paling terakhir adalah kopi dan gula yang dihapuskan (Ricklefs, 2008: 270).

Perbandingan areal perkebunan swasta dan perkebunan pemerintah yang ditanami tebu pada kurun waktu 18651914 sebagai berikut:

Tabel. 4 Perbandingan Areal Perkebunan Swasta dan Pemerintah yang Ditanami Tebu dari Tahun 1865 Sampai 1914. 


\begin{tabular}{|c|c|c|}
\hline Tahun & $\begin{array}{c}\text { Areal Perkebunan Swasta yang } \\
\text { Ditanami Tebu (ha) }\end{array}$ & $\begin{array}{l}\text { Areal Perkebunan Pemerintah } \\
\text { yang Ditanami Tebu (ha) }\end{array}$ \\
\hline 1865 & 4.280 & 29.019 \\
\hline 1865 & 9.878 & 27.441 \\
\hline 1879 & 10.370 & 27.441 \\
\hline 1880 & 12.131 & 25.352 \\
\hline 1881 & 14.176 & 23.254 \\
\hline 1882 & 16.552 & 21.176 \\
\hline 1883 & 19.998 & 18.746 \\
\hline 1884 & 24.239 & 16.682 \\
\hline 1885 & 28.269 & 14.428 \\
\hline 1886 & 28. 927 & 12.351 \\
\hline 1887 & 29.860 & 10.051 \\
\hline 1888 & 31.667 & 7.933 \\
\hline 1889 & 34.585 & 5.941 \\
\hline 1890 & 40.123 & 3.897 \\
\hline 1891 & 43.425 & 1.931 \\
\hline 1892 & 47.608 & - \\
\hline 1905 & 105.430 & - \\
\hline 1914 & 147.465 & - \\
\hline
\end{tabular}

(Cowan, 1961: 80)

Dalam pembiayaan oleh lembaga keuangan utama, kebun gula dan kopi mendominasi pada tahun 1884 dibanding hasil perkebunan lainnya. Turut hadirnya lembaga keuangan pada perkebunan gula dapat diartikan bahwa bisnis perkebunan gula memang memberikan daya tarik tersendiri hingga lembaga keuangan berani membiayai banyak pabrik gula, yang diantaranya sebagai berikut:

Tabel. 5 Perusahaan Dibiayai Lembaga Keuangan Utama Tahun 1884

\begin{tabular}{|c|c|c|c|c|}
\hline \multirow{2}{*}{ Bank } & \multicolumn{4}{|c|}{ Jumlah Perkebunan yang Dibiayai } \\
\cline { 2 - 5 } & Gula & Kopi & Lain-lain & Total \\
\hline N.I Handelsbank & 29 & 20 & 4 & 53 \\
\hline Int. Cred. Vereeniging & 12 & 20 & - & 32 \\
\hline Koloniale Bank & 9 & 17 & 12 & 38 \\
\hline Dorrepaal Co. & 22 & 38 & 53 & 113 \\
\hline
\end{tabular}


HISTORIA: Jurnal Program Studi Pendidikan Sejarah Volume 7 (2) 2019

ISSN 2337-4713 (E-ISSN 2442-8728)

\begin{tabular}{|c|c|c|c|c|}
\hline Handelsvereeniging & 4 & 2 & 1 & 7 \\
\hline
\end{tabular}

(Furnivall, 1944: 197)

\section{Krisis Malaise}

Perang Dunia I pada tahun 19141918 mengakibat kekacauan ekonomi yang luar biasa, dimana tempat-tempat yang menjadi sasaran hasil produksi kini kehilangan pasarnya. Beberapa Negara di dunia telah menjadi miskin karena peperangan. Misalnya Jerman, Austria dan Rusia, ekonomi kucar kacir, pertentangan -pertentangan terjadi untuk merebut daerah pemasaran baru untuk memperbaiki ekonomi yang telah hancur, sangat sukar di dapat (Soekarno, 1965: 592).

Krisis malaise merupakan krisis yang terjadi pada tahun 1929. Krisis ini biasa orang menyebutnya zaman meleset, karena segala usaha pada zaman itu tidak ada yang berhasil atau meleset.

Perang Dunia I menimbulkan kekacauan ekonomi yang luar biasa di dunia, Eropa, Amerika, bahkan sampai ke Hindia Belanda. Nasionalisme ekonomi menciptakan bea masuk yang tinggi dan menghentikan perdagangan internasional, maka timbullah kelebihan produksi di beberapa negara seperti USA, Brazilia, Canada, sehingga terjadilah kekurangan di negara lain. Kelebihan produksi mengakibatkan tertutupnya pabrik-pabrik dan menimbulkan pengangguran, akhirnya meletus dalam depresi ekonomi tahun 1923 dan tahun 1929-1930 yaitu masa malaise (Soebantardjo, 1960 : 170). Produksi berkembang namun pasar menyusut, khususnya untuk produk utama Jawa yaitu gula, sementara itu pinjaman yang dilakukan pemerintah dengan tingkat bunga tetap harus dibayar walaupun ada penurunan nilai hasil bumi Jawa (Diska,dkk, 2017 : 16).

Dampak dari krisis malaise juga berimbas kepada sektor perkebunan di Hindia Belanda, termasuk Industri Gula. Produksi gula yang meningkat secara continue turut merasakan imbasnya, karena pangsa pasar dunia yang lesu. Perang Dunia I bukan penyebab utama krisis malaise, penyebab utama adalah runtuhnya bursa saham New York yang mengakibatkan perekonomian Amerika Serikat ambruk pada rentang waktu beberapa tahun yaitu antara Tahun 1929-1933.

$\begin{array}{cc} & \text { Krisis Malaise ini berdampak } \\ \text { parah } & \text { terhadap }\end{array}$
perkebunan Belanda hingga menjadi benar-benar jatuh serta tingkat produksi perkebunan yang dikelola oleh pemerintah kolonial menurun secara drastis. Hampir semua komoditaskomoditas perkebunan yang laku keras di pasar ekspor mengalami penurunan 
yang cukup parah, karena selain komoditi perkebunan ini harus menyesuaikan dengan kebutuhan perang, perkebunan-perkebunan ini juga mengalami masalah yang sama, yaitu Malaise. Permintaan akan komoditi di pasaran dunia mengalami perubahan menyesuaikan dengan kebutuhan perang, hal ini berdampak terhadap jumlah produksi perkebunan yang cenderung menurun ( Kartodirjo, 1994:101).

Untuk mengatasi kebangkrutan industri gula, pemerintah melakukan pembatasan terhadap arus distribusi gula (Ela, 2016 : xviii). Padahal sebelum krisis malaise, pertumbuhan ekonomi Hindia Belanda sedang mengalami kenaikan secara signifikan (Dedi, 2017 : 60). Kelesuan ekonomi ini berpengaruh pada arus migrasi ke perkebunan maupun sektor industri lainnya, sebab pusat-pusat ekonomi tersebut mengalami penurunan dalam proses produksi. Pada masa krisis malaise banyak penduduk di wilayah perkebunan gula yang memilih bermigrasi ke sektor industri dan jasa (Larasati, 2016 : 13).

\section{PENUTUP}

\section{Kesimpulan}

Industri gula merupakan salah satu Industri di Hindia Belanda yang pernah memberikan prestasi yang gemilang dalam bidang ekspor. Pulau Jawa yang menjadi lokasi berdirinya pabrik-pabrik gula dinilai lokasi yang tepat karena dekat dengan pesisir pantai serta dari kontur tanah hingga padatnya penduduk Jawa, karena industri gula merupakan industri yang padat karya. Tahun 1930 kedatangan Van Den Bosch dengan sistem Cultuurstelsel (Tanam Paksa) mulai menekan penduduk dengan menyisihkan tanahnya untuk ditanami tebu serta tanaman ekspor lainnya. Kebijakan Van Den Bosch ditentang oleh para kaum kapitalis, yang memunculkan liberalisasi dengan membuat Undang-Undang Agraria Tahun 1870.

Undang-Undang Agraria pada tahun 1870 yang salah satunya berisi bahwa tanah milik rakyat merupakan titik peningkatan yang signifikan bagi indutri gula, karena banyak tanah yang disewakan kepada pihak swasta, dengan ini terbukalah kesempatan seluasluasnya untuk membuka usaha perkebunan. Produksi meningkat secara continue. Namun, efek perang Perang Dunia I hingga turunnya bursa saham New York yang dikenal dengan sebutan krisis Malaise berimbas kepada Negaranegara Eropa dan Asia, khususnya Hindia Belanda. produksi yang melimpah tanpa pangsa pasar yang tidak memadai membuat industri gula menekan produksinya secara drastis. Penurunan produksi di perkebunan tebu diikuti oleh perpindahan penduduk yang beralih ke sektor industri dan jasa. 


\section{DAFTAR PUSTAKA}

Abdurrahman, Dudung. (1999). Metode penelitan Sejarah. Jakarta: Logos Wacana Ilmu.

Abdurrahman, Dudung. (2011). Metode Penelitian Sejarah. Yogyakarta: Ombak.

Akob, Bachtiar, Teuku Junaidi. (2014). Malaise Dan Pengaruhnya Terhadap Gerakan Nasional Indonesia. Jurnal Seuneubok Lada. (ISSN; 2356-0770). Volume 2. Nomor 1. Halaman 16-30.

Basundoro, Purnawan. (2009). Dua Kota Tiga Zaman Surabaya dan Malang Sejak Kolonial Sampai Kemerdekaan. Yogyakarta: Ombak.

Basundoro, Purnawan. (2012). Pengantar Sejarah Kota. Yogyakarta: Ombak.

Breman, Jan. (1986). Penguasaan Tanah dan Tenaga Kerja di Jawa di Masa Kolonial. Jakarta: LP3ES.

Burger, D.H. (1960). Sejarah Ekonomi Sosiologis Indonesia, Djakarta: Prajnaparamita.

Cowan, D. (1961). Economic Development of Southeast-Asia, London.

Diniyah, Mufidatut. (2012). Sejarah Perkembangan Pabrik Gula Cepiring dan Pengaruhnya terhadap Kondisi Sosial Ekonomi Masyarakat Kendal Tahun 19751997. Journal of Indonesia History (ISSN; 2252-6633). Volume 1. Nomor 1, Halaman 36

Diska, dkk. (2017). Krisis Ekonomi di Banyumas 1930-1935 Sampai Perpindahan Pusat Pemerintahan dari Banyumas ke Purwokerto Tahun 1937. Journal of Indonesian History. (ISSN; 2252-6633). Volume 6. Nomor 1. Halaman 16.

Fasseur, Cornelis. (1992). The Politics of Colonial Exploitation, Java, The
Dutch, and the Cultivation System. Cornell University Press.

Furnivall, J. (1944). Netherlands India, Cambridge

Gonggrijp, G. 1938. Schetseener Economische Geschiedenis van Neder landsch-Indie, Haarlem

Gottschalk, L. (2008). Mengerti Sejarah. Jakarta: Universitas Indonesia.

Ham, Ong Hok. (2002). Soal Priyayi sampai Nyi Blorong: Refleksi Historis Nusantara, Jakarta: Kompas

Handinoto. (2015). Perkembangan Kota Di Jawa Abad XVII Sampai Pertengahan Abad XX Dipandang dari Sudut Bentuk dan Struktur Kotanya. Yogyakarta: Ombak.

Irwanto, Dedi. (2017). Malaise dan Lambang Kekayaan Ekonomi Penguasa Lokal di Palembang, 1929-1942. Lembaran Sejarah. (ISSN; 2620-5882). Volume 13. Nomor 1. Halaman 60.

Kano, Hiroyosi dkk, Di Bawah Asap Pabrik Gula Masyarakat Desa di Pesisir Jawa Sepanjang Abad Ke20, Yogyakarta: Gajah Mada University Press.

Kartodirjo \& Suryo. (1991). Sejarah Perkebunan di Indonesia: Kajian Sosial Ekonomi, Yogyakarta: Aditya Media.

Kartodirjo, Sartono. (1994). Sejarah Perkebunan Di Indonesia. Yogyakarta : Aditya Media

Kuntowijoyo. (1994). Pengantar Ilmu Sejarah. Yogyakarta: Benteng Budaya.

Larasati, Sri. (2006). "Pengaruh Krisis Malaise Terhadap Pabrik Gula Gondang Winangun Tahun 19291940", Skripsi. Yogyakarta: Universitas Negeri Yogyakarta. 
Leirissa, R.Z dkk. 2012. Sejarah Perekonomian Indonesia, Yogyakarta: Ombak.

Mutiara, Triesca Dewi Sri Mastuti Purwaningsih. (2016). SUIKERSNDICAAT Hindia Belanda 1870-1941. Jurnal AVATARA. (ISSN;2354-5569). Volume 4, Nomor 3, halaman 656-663.

Poesponegoro \& Notosusanto, (1984). Sejarah Nasional Indonesia IV. Jakarta: PN Balai Pustaka.

Poesponegoro \& Notosusanto. (1984). Sejarah Nasional Indonesia $V$ Zaman Kebangkitan Nasional dan Masa Hindia Belanda. Jakarta: Balai Pustaka.

Putriningtyas, Ela Aprilia, "Industri Perkebunan Tebu di residensi Madiun Pada Masa Akhir Kolonial (1900-1942), Skripsi, Surakarta: Universitas Sebelas Maret. 2016.

Raffles, Thomas Stamford. (2008). The History of Java. Yogyakarta: Narasi

Ricklefs, M.C. Sejarah Indonesia Modern 1200-2008, Jakarta: PT. Serambi Ilmu Semesta.

Saffanah, Winin Maulidya. (2018). Industrialisasi dan Berkembangnya Kota Malang Pada Awal Abad Ke20. Jurnal Agastya (ISSN; 20878907), Volume 8, Nomor 2, halaman 167-180.

Sasmita, Nurhadi. (2011). Industrialisasi di Gementee Blitar, 1900 - 1942.
Jurnal Sejarah Citra Lekha (ISSN; 2443-0110). Volume XV. Nomor 2, Halaman 1-18.

Sholeh, Kabib. (2019). Pelayaran Perdagangan Sriwijaya dan Hubungannya dengan Negerinegeri luar pada abad VII-IX Masehi. Jurnal HISTORIA (ISSN; 2337-4713). Volume 7, Nomor 1, Halaman 1-21.

Soebantardjo. (1960). Sari Sejarah Jilid II. Yogyakarta: Bokpri

Soekarno. (1965). Di Bawah Bendera Revolusi, Jilid I. Panitia Dibawah Bendera Revolusi.

Susilo, Agus, Isbandiyah. (2018). Politik Etis dan Pengaruhnya bagi Lahirnya Pergerakan Bangsa Indonesia. Jurnal HISTORIA (ISSN; 2337-4713). Volume 6, Nomor 2, Halaman 403-416.

Trijono. (2011). Djember 1859-1929 Melacak Sebuah Kota Berbasis Perkebunan di Jawa Timur, Bali: Cakra Press.

Van Niel, Robert. (2007). Sistem Tanam Paksa Di Jawa. Jakarta: Pustaka LP3ES Indonesia.

Wasino. (2014). Modernisasi Di Jantung Budaya Jawa, Jakarta: PT. Kompas Media Nusantara.

Yass, Marzuki. (2004). Metodologi Sejarah dan Historiografi. Palembang: Proyek SP4 Universitas Sriwijaya. 